\title{
PEDIS Score Analysis in Diabetic Foot Ulcer following Angioplasty Revascularization Procedure \\ Ridho Sinaga ${ }^{*}$, Djony Tjandra ${ }^{2}$, Richard Sumangkut ${ }^{2}$, Billy Karundeng ${ }^{2}$, Fima Langi ${ }^{5}$
}

Background: Diabetic foot ulcers (DFU) is one of the major health care problems. Diabetic foot ulcers are a combination of vascular and non-vascular disorders. Vascular disorders that occur in the form of diabetic angiopathy which can be in the form of macro angiopathy if the condition occurs in large blood vessels, and micro angiopathy if it occurs in arterioles and capillaries. Revascularization can be done minimally invasive and has become the gold standard in the management of chronic limb ischemic (CLI). WHO recommends Perfusion, Extent / Size, Depth / Tissue Loss, Infection, Sensation (PEDIS) classification to diagnose and to determine the management of diabetic foot. We conduct a study to find out whether there are improvements in the PEDIS score of diabetic foot ulcer patients post angioplasty

Methods: This study was designed in the form of a quasi-experiment, in which measurements before and after treatment were carried out on patients with diabetic foot ulcers (DFU) who underwent revascularization angioplasty without any measurement for control patients. From November 2019 to September 2020, there were 48 cases of diabetic foot ulcer with peripheral artery disease (PAD) who underwent angioplasty. Before the procedure, a clinical evaluation and calculation of the PEDIS score were carried out then angioplasty was performed, after the procedure the PEDIS score was calculated and evaluated in the first, second and third weeks.

Results: The PEDIS scores of the patients prior to angioplasty had a median score of 8 (IQR 7; 9). Post-procedure the median quantity fell to 6 on both the immediate post angioplasty and two weeks afterward measurement with the width of the IQR narrowing slightly at the last measurement. The male patients' PEDIS scores did not differ relatively from those of the female patients at the three measurement times, and their scores were almost identical to the scores for the patients as a whole.

Conclusion: The results of this study indicate that there is an improvement in the PEDIS score in diabetic foot ulcer patients after revascularization angioplasty.

Keywords: diabetic foot, angioplasty, revascularization, PEDIS score

https://doi.org/10.36864/jinasvs.2021.1.007

*Correspondence: ridhosinaga7@gmail.com

${ }^{1}$ General Surgery Resident, Departement of Surgery, Faculty of Medicine, University of Sam Ratulangi, Manado

${ }^{2}$ Departement of Vascular Surgery, Faculty of Medicine, University of Sam Ratulangi, Manado

${ }^{3}$ Departement of Public Health Sciences, Faculty of Medicine, University of Sam Ratulangi, Manado

\section{INTRODUCTION}

Diabetic foot ulcer is one of the major health care problems and it also contributes greatly to social problems related to costs for people with diabetes mellitus (DM). It is estimated that there are around 422 million people worldwide suffering from diabetes in 2014.1,2 According to the Riset Kesehatan Dasar (Riskesdas)/ Primary Health Research report from the Ministry of Health of the Republic of Indonesia in 2013, the proportion of people with diabetes in Indonesia have reached $6.9 \%$ with an estimation of $176,689,336$ on people aged over 15 years in Indonesia, thus it is estimated that the absolute
Copyright (C) 2021, The Indonesian Society for Vascular and Endovascular Surgery

JINASVS 2021;2(1):20-25 
Table 1. Characteristics of Diabetic Foot Ulcer Patients

\begin{tabular}{|c|c|c|c|c|c|c|c|}
\hline \multirow[b]{2}{*}{ Characteristics } & \multicolumn{2}{|c|}{ Total $(N=48)$} & \multicolumn{2}{|c|}{ Male $(n=24)$} & \multicolumn{2}{|c|}{ Female $(n=24)$} & \multirow[b]{2}{*}{$p^{a}$} \\
\hline & $\begin{array}{c}\mathrm{n}(\%) \text { or } \\
\text { Mean (SD) }\end{array}$ & $\begin{array}{c}\text { Median (Q1; } \\
\text { Q3) }\end{array}$ & $\begin{array}{l}\mathrm{n}(\%) \text { or } \\
\text { Mean (SD) }\end{array}$ & $\begin{array}{c}\text { Median (Q1; } \\
\text { Q3) }\end{array}$ & $\begin{array}{l}\mathrm{n}(\%) \text { or } \\
\text { Mean (SD) }\end{array}$ & $\begin{array}{c}\text { Median (Q1; } \\
\text { Q3) }\end{array}$ & \\
\hline Age & $61,7(9,0)$ & $*$ & $59,8(8,0)$ & $*$ & $63,6(9,6)$ & $*$ & 0,141 \\
\hline $\begin{array}{l}\text { Hemoglobin } \\
(\mathrm{g} / \mathrm{dL})\end{array}$ & * & $\begin{array}{c}9,3(8,6 \\
10,0)\end{array}$ & * & $\begin{array}{c}9,5(9,0 \\
10,6)\end{array}$ & * & $8,9(8,1 ; 9,6)$ & 0,039 \\
\hline $\begin{array}{l}\text { Leucocytes } \\
(\times 103 / \mu \mathrm{L})\end{array}$ & $*$ & $\begin{array}{c}12,8(8,6 ; \\
18,6)\end{array}$ & * & $\begin{array}{c}12,8(8,9 ; \\
13,9)\end{array}$ & * & $\begin{array}{c}12,7(8,1 ; \\
21,2)\end{array}$ & 0,606 \\
\hline $\begin{array}{l}\text { Platelets } \\
(\times 103 / \mu \mathrm{L})\end{array}$ & $\begin{array}{c}314,0 \\
(104,6)\end{array}$ & $-0,0$. & $\begin{array}{c}319,8 \\
(104,8)\end{array}$ & $-0,-1$ & $\begin{array}{c}308,1 \\
(106,4)\end{array}$ & $-1-1$ & 0,704 \\
\hline Urea (mg/dL) & * & $\begin{array}{c}54,5(23,5 \\
80,0)\end{array}$ & $*$ & $\begin{array}{c}55,0(32,2 ; \\
81,5)\end{array}$ & $*$ & $\begin{array}{c}52,5(20,8 \\
68,5)\end{array}$ & 0,293 \\
\hline $\begin{array}{l}\text { Creatinine } \\
\text { (mg/dL) } \\
\text { PEDIS Score }\end{array}$ & * & $1,4(0,9 ; 1,9)$ & $*$ & $1,6(0,9 ; 2,2)$ & $*$ & $1,2(0,9 ; 1,8)$ & 0,235 \\
\hline Pre-Angioplasty & * & $8,0(7,0 ; 9,0)$ & * & $8,0(7,0 ; 9,0)$ & * & $8,0(7,0 ; 9,0)$ & 0,941 \\
\hline Post Angioplasty & * & $6,0(5,5 ; 7,0)$ & $*$ & $6,0(5,0 ; 7,0)$ & $*$ & $6,0(6,0 ; 6,8)$ & 0,642 \\
\hline $\begin{array}{l}2 \text { Weeks Post } \\
\text { Angioplasty }\end{array}$ & $*$ & $6,0(5,0 ; 6,0)$ & $*$ & $6,0(5,0 ; 6,0)$ & $*$ & $6,0(6,0 ; 6,0)$ & 0,223 \\
\hline
\end{tabular}

Note: SD standar deviation, Q1 Quartile I, Q3 Quartile III. a Result uji $t$ or Mann-Whitney $U$ on numeric variables, test $x 2$ or Fisher's Exact on Categorical Variables.

population increases up to $10-20$ times compared to the non-diabetic patients. Approximately $70 \%$ to $80 \%$ of all non-traumatic amputations occur in diabetic patients. $^{5}$ Diabetic foot ulcers are a combination of vascular and non-vascular disorders. Vascular disorders occur in the form of diabetic angiopathy; which can form macro angiopathy if the condition occurs in large blood vessels, alternately micro angiopathy if it occurs in arterioles and capillaries. ${ }^{6}$ The progress of diabetic foot ulcers is a combination of ischemic problems, peripheral neuropathies and infections. ${ }^{7}$
WHO recommends Perfusion, Extent / Size, Depth / Tissue Loss, Infection, Sensation (PEDIS) classification to diagnose and to determine the management of diabetic foot. ${ }^{8}$ In several studies using the PEDIS classification, it predicts the needs for hospital treatments and amputations in diabetic foot patients which only reviewed from the infection aspect. 8,9 Patients with diabetic foot ulcer require a longer healing time and comprehensive multidisciplinary managements, ranging from controled of blood sugar levels, the use of antibiotics, debridement of the ulcer, wound care, offloading and

Table 2. Distribution of PEDIS Scoring System Data on Diabetic Foot Ulcer Patient

\begin{tabular}{ll}
\hline Variable & $\begin{array}{l}\text { Diabetic Foot } \\
\text { Ulcer }\end{array}$ \\
\hline Perfusion & \\
Grade I, No PAD (0) & 0 \\
Grade II, PAD (1) & $39(81,2 \%)$ \\
Grade III, CLI (2) & $9(18,8 \%)$ \\
Extent & \\
Grade I, skin intact (0) & 0 \\
Grade II, < $1 \mathrm{~cm}^{2}(1)$ & 0 \\
Grade III, 1-3 cm $\mathrm{cm}^{2}(2)$ & $4(8,3 \%)$ \\
Grade IV, >3 cm ${ }^{2}(3)$ & $44(91,7 \%)$ \\
Depth & \\
Grade I, skin intact (0) & 0 \\
Grade II, Superficial (1) & $6(12,5 \%)$ \\
Grade III, Fascia Muscle, tendon (2) & $27(56,2 \%)$ \\
Grade IV, bone or joint (3) & $15(31,3 \%)$ \\
Infection & \\
Grade I, none (0) & $2(4,2 \%)$ \\
Grade II, Surface (1) & $15(31,3 \%)$ \\
Grade III, Abscess, fasciitis, septic arthritis & $28(58,3 \%)$ \\
(2) & $3(6,25 \%)$ \\
Grade IV, SIRS (3) & \\
Sensation & $40(83,3 \%)$ \\
Grade I, No loss (0) & $8(16,7 \%)$ \\
Grade II, Loss (1) & \\
Total PEDIS Score & $4(8,3 \%)$ \\
5 & $3(6,25 \%)$ \\
6 & $7(14,6 \%)$ \\
7 & $17(35,4 \%)$ \\
8 & $9(18,7 \%)$ \\
9 & $4(8,3 \%)$ \\
10 & $3(6,25 \%)$ \\
11 & \\
\hline &
\end{tabular}




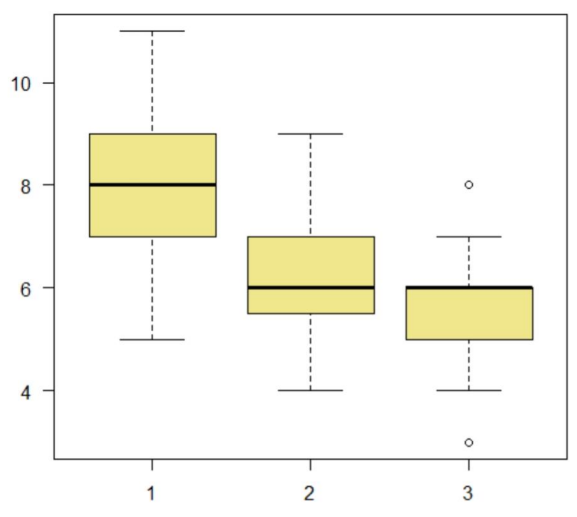

Figure 1. PEDIS Score of Diabetic Foot Ulcer Patients on (1) Pre, (2) Post, and (3) Two Weeks Post Angiography Measurements

revascularization of ischemic diabetic ulcers, but so far there is no satisfactory treatment method. ${ }^{10}$ Revascularization can be done openly and has become the gold standard in the management of chronic limb ischemic (CLI). However, the morbidity of an open revascularization is higher than that of endovascular interventions, so it is slowly being replaced by endovascular interventions in the last two decades. The advantages of endovascular intervention such as it can be performed under local anesthesia to prevent complications of general anesthesia, avoiding ischemic leg incisions, better wound healing, reduced cardiovascular stress, earlier recovery and outpatient care, and easier reintervention when needed. ${ }^{11,12}$ Diabetic foot ulcer intervention can be in the form of Surgical by-pass or using an endovascular intervention approach such as percutaneous transluminal angioplasty (PTA). Both of these produce good results, but the re-intervention incidence in the surgical by-pass is more frequent than percutaneous transluminal angioplasty (PTA). A study conducted by Mala et al, showed that the surgical by-pass approach received $54 \%$ more reintervention in 2 years postoperative time than percutaneous transluminal angioplasty (PTA). ${ }^{13}$

Research by Namgong et al found that patients who underwent PTA had better recovery rates assessed by the value of the transcutaneous measurement of the partial oxygen pressure (TcPO2) which increased by around $32.8 \mathrm{mmHg}$ for 6 weeks post PTA. ${ }^{14}$ Research by Abdelmieniem et al found that the treatment of PTA in diabetic patients with infrapopliteal disease is a safe and effective choice, the PEDIS score represents the most significant angiographic parameter for evaluating the possibility of ulcer healing and its consequences. ${ }^{15}$ Based on those literatures, we hereby conduct a study to find out whether there are improvements in the PEDIS score of diabetic foot ulcer patients post angioplasty.

\section{METHOD}

This study was designed in the form of a quasi experiment, in which it measures patients with diabetic foot ulcers who underwent revascularization angioplasty before and after treatment without any measurement for control patients. The absence of such a comparison group was inevitable, because according to standard procedures for diabetic foot ulcer patients with indications for angioplasty, this procedure has to be performed. Thus, the absence of a control group of patients without angioplasty performed occurred for ethical reasons. There were 48 cases of diabetic foot ulcer with peripheral artery disease (PAD) who underwent angioplasty during the study period. Patient data in the study taken from a November 2019 to September 2020, data processing was done in the Surgery Department of Prof. R D Kandou Manado General Hospital. Angioplasty was performed in a cath lab with diagnostic and intervention facilities according to the Standard Operating Procedure. The operators are specialists in vascular surgery. Before the procedure, a clinical evaluation and calculation of the PEDIS score were carried out then angioplasty was performed, after the procedure the PEDIS score was calculated and evaluated in the first, second and third weeks. The research was conducted in accordance to human subject research ethical principles and had received ethical clearance from the Commission on Ethical Research.

\section{RESULT}

\section{Characteristic of the Subject}

Forty-eight diabetic foot ulcer patients participated in the study. The men and women had the same ratio. Their characteristics of the participants are summarized in Table 1 . The median age of the patients was 62 years with a deviation of approximately 9 years. Female patients had a higher median age than male but the difference between them was not significant $(p=0.141)$. In general, these patients were anemic with a median hemoglobin level of about $9 \mathrm{~g} / \mathrm{dL}$. Table 1 . shows that this characteristic was quite different between the sexes

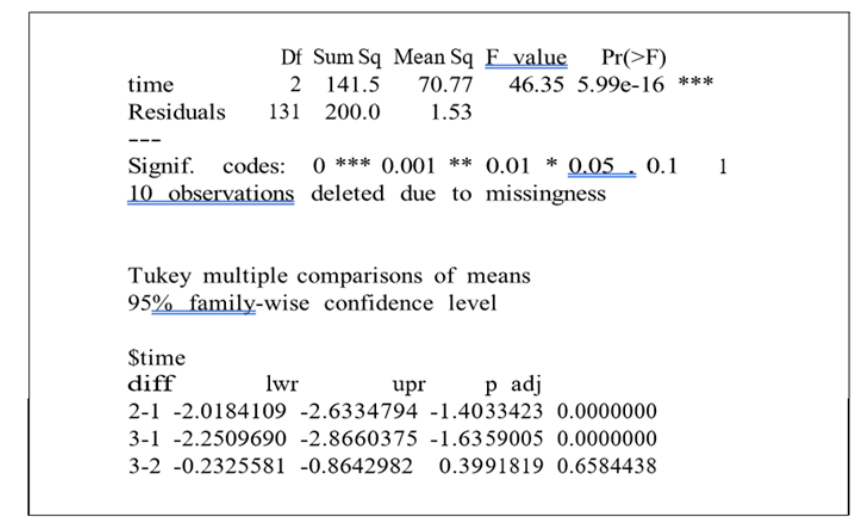

Figure 2. Results of ANOVA analysis dan post hoc Tukey HSD test. 
Table 3. Random Intercept Model from PEDIS Scoring System on Diabetic Foot Ulcer Patient Pre and Post Angioplasty

\begin{tabular}{lcccc}
\hline & \multicolumn{4}{c}{ PEDIS Score } \\
\cline { 2 - 5 } Time & Univariable Model & \multicolumn{2}{c}{ Multivariable Model } \\
\cline { 2 - 5 } $\begin{array}{l}\text { Pre-Angioplasty } \\
\text { (ref) }\end{array}$ & $*$ & $*$ & & \\
Post Angioplasty & $-1,78(-1,95 \%-1,58)$ & $<0,001$ & $-1,77(-1,97 ;-1,57)$ & $<0,001$ \\
2 Weeks Post & $-2,01(-2,21 ;-1,81)$ & $<0,001$ & $-2,00(-2,20 ;-1,81)$ & $<0,001$ \\
Angioplasty & &
\end{tabular}

Note: CI confidence interval. a Model multivariable control for gender variation, age, hemoglobin,

leucocytes, platelets, urea and creatinine

$(p=0.039)$, but the difference in the median values of them ( 9.5 and $8.9 \mathrm{~g} / \mathrm{dL}$ for men and women respectively) is relatively insignificant clinically, urea and creatinine levels tend to be high with a median of 54.5 (IQR 23.5; 80.0) $\mathrm{mg} \mathrm{/} \mathrm{dL}$ and 1.4 (IQR), respectively. $0.9 ; 1.9) \mathrm{mg} / \mathrm{dL}$. In general, these patients also had leukocytosis with a median leukocyte counts of nearly $13,000 / \mu \mathrm{L}$. The average platelet counts was within the normal limits. There were no differences in the levels of leukocytes and platelets count in both sexes. Meanwhile, urea and creatinine levels tend to be high, with a median of 54.5 (IQR 23.5; 80.0) $\mathrm{mg} / \mathrm{dL}$ and 1.4 (IQR 0.9; 1.9) $\mathrm{mg} / \mathrm{dL}$, respectively. This situation did not differ much in male and female patients.

The PEDIS score of the patients prior to angioplasty had a median score of 8 (IQR 7; 9). Postprocedure the median quantity fell to 6 on both the immediate post angioplasty and two weeks post angioplasty measurement with the width of the IQR narrowing slightly at the last measurement. The male and female patients' PEDIS scores relatively indifferent at the three measurement times, and their scores were also nearly identical to the scores of the patients as a whole.

Table 2. shows the distribution of PEDIS scores on diabetic foot ulcers patient. In Perfusion criteria, $81.3 \%$ of the patients had Peripheral Artery Disease (PAD) and $18.2 \%$ had Critical Limb Ischemic (CLI). $91.7 \%$ of the patients had an ulcer size of more than $3 \mathrm{~cm}^{2}$. Most of the wound depth was grade 3 with a percentage of $56.2 \%$. Infections were found mostly in the fascia, muscles, tendons by $56.2 \%$. Sensory loss experienced by $83.3 \%$ of the patients. Total PEDIS score $\leq 7=14.6 \%$, score $\geq 7=85.4 \%$.

Figure 1. showed a distinct reduction (improvement) in the post angioplasty-PEDIS score. This improvement was more distinguishable before and immediately after the angioplasty than in the other two measurements after the procedure.

The results of the ANOVA analysis as shown in Figure 2. confirm the difference in PEDIS scores across the three measurements $(p<0.001)$. The post hoc Tukey HSD test indicates a significant differences between the first and second measurements, and between the first and third measurements, but no statistically significant differences between the second and third measurements.

To complement the results earlier shown in Table 1, Figure 1 . showed a distinct reduction (improvement) in the post angioplasty-PEDIS score. This improvement was more distinguishable before and immediately after the angioplasty than in the other two measurements after the procedure. The results of the ANOVA analysis as shown in Figure 2. confirm the difference in PEDIS scores across the three measurements $(p<0.001)$. The post hoc Tukey HSD test indicates a significant differences between the first and second measurements, and between the first and third measurements, but no statistically significant differences between the second and third measurements.

Table 3. shows the improvement in the PEDIS score after angioplasty, the patients had an average PEDIS score improvement of 1.78 points after angioplasty, and at the end of the second week after angioplasty the improvement reached about 2.01 points, when compared with the PEDIS score before the procedure. After the variability of other variables in the data was controlled, the improvement in the PEDIS score after angioplasty and two weeks afterwards was 1.77 (95\% CI $-1.97 ;-1.57$ with $p$ $<0.001)$ and 2.00 ( $95 \%$ CI $-2.20 ;-1.81$ with $p$ $<0.001$ ) points respectively.

\section{DISCUSSION}

Diabetic foot is one of the most feared and common complications in diabetic patient because it brings disability and even death. Diabetic foot is also a primary cause of nontraumatic amputation on the inferior limb. Thus, it becomes an economic burden not only for patients but also for the health institutions.

Prior from November 2019 to September 2020 , there were 48 cases of diabetic foot ulcers in the Surgery Department of Prof. DR.R.D. Kandou Manado. They were 24 men and 24 women. In other epidemiological studies of diabetic foot ulcers in Romania (2008), Sydney (2011), and Egypt (2012), showed that male has the highest incidence of diabetic foot ulcers, with a ratio of $2: 1.16,17,18$ While Kristiani study in Manado (2015) found more incidence on women than men, so that the gender differences in some research were not the same. ${ }^{19}$ However, the theory in the literature review showed that male gender has a higher risk factor for diabetic foot.

The median age of the patients was 62 years with a deviation of approximately 9 years. Female patients had a higher median age than male but the difference between them was not significant ( $p=$ 0.141 ). Studies by Zaine et al. and Nwabudike et al. showed that the highest incidence of diabetic foot ulcers was in the 6th decade. Research in America also reports that the highest percentage of diabetic foot is at the age of 45-64 years. ${ }^{20,21}$

In general, these patients were anemic with a median hemoglobin level of about $9 \mathrm{~g} / \mathrm{dL}$, this characteristic was quite different between the sexes $(p=0.039)$, but the difference in the median values of them $(9.5$ and $8.9 \mathrm{~g} / \mathrm{dL}$ for men and women respectively) is relatively insignificant clinically, urea and creatinine levels tend to be high with a median of 54.5 (IQR 23.5; 80.0) $\mathrm{mg} / \mathrm{dL}$ and 1.4 (IQR), respectively. $0.9 ; 1.9) \mathrm{mg} / \mathrm{dL}$. This situation is 
indifferent in male and female patients, a decrease in hemoglobin levels and an increase in kidney function is confirmed by the study of Clara Adelia Wijaya et al (2015). . $^{22}$

In general, these patients also had leukocytosis with a median leukocyte counts of nearly $13,000 / \mu \mathrm{L}$, the same as a study by Anak Agung Ayu Rosita et al (2017). ${ }^{23}$ The average platelet counts was within the normal limits.

In Perfusion criteria, $81.3 \%$ of the patients had Peripheral Artery Disease (PAD) and $18.2 \%$ had Critical Limb Ischemic (CLI). $91.7 \%$ of the patients had an ulcer size of more than $3 \mathrm{~cm} 2$. Most of the wound depth was grade 3 with a percentage of $56.2 \%$. Infections were found mostly in the fascia, muscles, tendons by $56.2 \%$. Sensory loss experienced by $83.3 \%$ of the patients. Total PEDIS score $\leq 7=14.6 \%$, score $\geq 7=85.4 \%$.

The PEDIS score of the patients prior to angioplasty had a median score of 8 (IQR 7; 9). Postprocedure the median quantity fell to 6 on both the immediate post angioplasty and two weeks post angioplasty measurement with the width of the IQR narrowing slightly at the last measurement.

Mark Rockley et al (2020) stated that the changes in the ABI (perfusion) value can be seen after one day post procedure and lasted for one month, the study also showed the (Perfusion, Infection) score had significantly improved, while (Extent, Depth, Sensation) score showed minimal improvement during the study time because it took a longer time to heal ulcers. ${ }^{24}$ The male and female patients' PEDIS scores relatively indifferent at the three measurement times, and their scores were also nearly identical to the scores of the patients as a whole.

The patients had an average PEDIS score improvement of 1.78 points after angioplasty, and at the end of the second week after angioplasty the improvement reached about 2.01 points, when compared with the PEDIS score before the procedure. After the variability of other variables in the data was controlled, the improvement in the PEDIS score after angioplasty and two weeks afterwards was 1.77 (95\% CI $-1.97 ;-1.57$ with $\mathrm{p}<0.001)$ and $2.00(95 \% \mathrm{CI}-$ $2.20 ;-1.81$ with $\mathrm{p}<0.001)$ points respectively.

The maximum score for PEDIS is 12 , while scores of above 7 is difficult to recover. In this study, it showed most of the patients score were $8(35.4 \%)$, followed by a score of $9(18.7 \%), 7(14.6 \%), 5$ and $10(8.3 \%)$, and a score of 6 and $11(6.25 \%)$.

Diabetic ulcers occur because of two mechanisms, which is angiopathy and neuropathy. Ulcers can occur as a result of either one or both of these mechanisms. Ulcers can be worse depending to the severity of the tissue ischemia.

As a summary, this research shows a distinct reduction (improvement) in the post angioplastyPEDIS score. This improvement was more distinguishable before and immediately after the angioplasty than in the other two measurements after the procedure. The results of the ANOVA analysis as shown in Figure 2. confirm the difference in PEDIS scores across the three measurements $(p<0.001)$. The post hoc Tukey HSD test indicates a significant differences between the first and second measurements, and between the first and third measurements, but no statistically significant differences between the second and third measurements.

Statistics and research show that the degree of ischemia, ulcer dimension, infection and sensory influence the occurrence of diabetic ulcers. Special attention should be given to the diabetic foot patients to prevent ulcers by controlling risk factors, identifying threatened limbs, and educating people with diabetes. Prevention of nontraumatic limb amputation due to diabetes must be a top priority, by examining the circulation of the inferior extremities, especially in patients with diabetes who have cardiovascular risk factors. For this reason, the authors recommend limbs monitoring in patients as mentioned above.

\section{CONCLUSION}

Special attention should be given to the diabetic foot patients to prevent ulcers by controlling risk factors, identifying threatened limbs and educating people with diabetes. Prevention of nontraumatic limb amputation due to diabetes must be a top priority, by examining the circulation of the inferior extremities, especially in patients with diabetes who have cardiovascular risk factors. For this reason, the authors recommend limbs monitoring in patients as mentioned above. The results of this study indicates that there was an improvement in the PEDIS score in diabetic foot ulcer patients after revascularization angioplasty

\section{CONFLICT OF INTEREST}

The author states the original work, and there is no conflict of interest in doing this research.

\section{ORCID ID OF AUTHORS}

\section{REFERENCES}

1. Roglic G, World Health Organization, editor. Global report on Diabetes. Geneva: World Health Organization; $2016.86 \mathrm{hlm}$.

2. Stoekenbroek RM, Santena TB, Legemate DA, Ubbink DT Van den Brink A, Koelamay MJW. Hyperbaric Oxygen for Treatment of diabetic foot ulcer: a Systematic review. Eur J Vasc Endovasc Surg. Juni 2014; 47 (6):647-55.

3. Badan Penelitian dan Pengembangan Kesehatan, Kementrian Kesehatan RI. Riset kesehatan dasar 2018. Jakarta: Kementrian Kesehatan RI 2018.

4. Rianty Rahalus, Asrial ASrifuddin, Wulan PJ Kaunang. Faktor factor yang berhubungan dengan kejadian diabetes melitus tipe 2 di manado 2017. Ejournal Unsrat. 
5. Nouvong Aksone, Amstrong DG. Diabetic doot ulcer. Dalam: Cronenwett J, Jhonston KW, editor. Rutherford's Vaskular Surgery. $8^{\text {th }}$ ed. Philadelphia:Ellsevier Saunders;2014.

6. Pengurus Besar Perkumpulan Endokrinologi Indonesia. Konsensus Pengelolaan dan pencegahan DM tipe 2 di Indonesia, Ed 4 Jakarta: Divisi Metabolik Endokrinologi Departemen Ilmu Penyakit Dalam. Jakarta; BP FKUI.2011.p.1-2.

7. Soegondo S, Soewondo P, Subekti I. Penatalaksanaan Diabetes Melitus Terpadu: Komplikasi Akut Diabetes Melitus, Ed 8. Jakarta: BP FKUI.2011.p.11-45.

8. Alberti KG, Zimmet $P$, Shaw J. International Diabetes Federation: a consensus on Type 2 diabetes prevention. Diabetic Med.2007; 24(5):451-63.

9. Lipsky B, Anthony R, Paul B, James C, Edgar J, dkk. Infection Diseases Society of America clinical practice guidelines. Clin infect dis. 2012;54(12): 132-73.

10. Kessler L, Bilbaut P, Ortega F, Grasso C, Passemard R, Stephan D, dll. Hyperbaric oxygenation accelerates the healing rate of non-ischemic chronic diabetic foot ulcers: a prospectif Randomized study. Diabetic care. 1 Agustus 2003; 26(8):2378-82.

11. Slovut DP, Sullivan TM, Critical Limb Ischemia: medical and surgical management. Vasc Med J.2008(13). 281-91. E pub Aug 7, 2008.

12. Okhi T. A review of Endovaskular Option of Critical Limb Ischemia. Endovaskular Today. 2006:60-6. Epub September 2006.

13. Mahmoud B Malas,MD,MHS; Umair Qazi,MD,MPH; Natalia Gebova,MD, dkk. Design of the Revaskularization with open bypass Vs Angioplasti and stenting of the lower extremity trial (ROBUST), A randomized Clinical Trial. JamaSurg.2014;149(12):1289-1295.

14. Namgoong $\mathrm{S}$, Jong-phil Yang, dkk. Comparison of perfusion value after percutaneous transluminal Angioplasti according to the severity of ischemia in the diabetic foot. Int wound J.2018;16: 176-182.

15. Abdelmieniem $\mathrm{F}$ et al. Predictive value of angiographic Charateristic for endovaskular revaskularization of the ischemic diabetic foot. The Egyptian Journal of Surgery.2018,37:294-303.

16. Bishara RA, Taha W, Akladious I, Allam MA. Ankle peak systolic velocity: new parameter to predict nonhealing in diabetic foot lesions. Vaskular. 2009. 17(5):264-8

17. Zaine MH, Burns J, Vicaretti M, Fletcher JP,Begg L, Hitos K. Characteristic of diabetic foot ulcers in Western Sidney, Australia. Journal of Foot and Ankle Research. 2014. 7:39

18. Rizk MN, Ameen AI. Comorbidities associated with Egyptian diabetic foot disease subtypes. The Egyptian Society of Internal Medicine. 2013

19. Kristiani AL, Sumangkut $R$, Limpeleh $H$, Hubungan Ankle Brachial Index dengan keparahan ulkus pada penderita kaki diabetic di RSU Prof Kandou (Karya akhir). Manado, 2015. 40 p.

20. Nwabudike LC, Tirgoviste CI. Risk factors and clinical characteristic for foot ulcers in patients with diabetes in Bucharest, Romania. Proc Rom Acad. 2008;1-2:49-52.

21. Zaine MH, Burns J, Vicaretti M, Fletcher JP, Begg L, Hitos K. Characteristic of diabetic foot ulcers in Western Sidney, Australia. Journal of Foot and Ankle Research. 2014; 7:39

22. Clara AW,Yulianto K,Nyanyu FZ. Korelasi antara hemoglobin dan gangguan fungsi ginjal pada diabetes mellitus tipe 2 di RSUP dr Mohammad Hoesin Palembang.Januari 2015 MKS, Th.47, no 1.

23. Anak AAR,Tjocorda GO,Didik P. Perbandingan jumlah leukosit pada penderita diabetes mellitus yang mengalami gangren diabetic dengan yang tidak mengalami gangrene di RSUD Kabupaten Badung.2017.

24. Mark R,Prasad J,George W. Physiologic perfusion monitoring methods during endovascular revascularization for atherosclerotic peripheral arterial disease : protocol for a systematic review. May 2020. 